\title{
Physicochemical Quality of Cow Raw Milk Produced in the Fkih
}

\section{Ben Saleh Area}

\author{
Lhou Ouhida ${ }^{1}$, Rachid Hnini ${ }^{1}{ }^{*}$, Said Ihbour $^{1}$, Chigr Fatiha ${ }^{1}$ and Mohamed Najimi ${ }^{1}$ \\ ${ }^{1}$ Laboratory of Biological Engineering, Pathology and Functional Biology Team \\ Sultan Moulay Slimane University, FST,
}

PO.Box: 523, 23000

Beni Mellal, Morocco.

\begin{abstract}
The main objective of the present study was to evaluate the physicochemical quality of raw cow milk produced in Fkih Ben Saleh, one of the major milk production areas in Beni Mellal-Khenifra region in Morocco located in the North-Centre of Morocco. Physicochemical quality of raw milk was determined by assessing the analysis of Fat Content "FC", Protein Content "PC", Total Solids "TS", Solids No-Fat "SNF", Acidity "Ac", Brix "Bx", Density "Ds", Temperature "To" and Alcohol Test "AT", using recognized standardized methods and infrared methods for better assessing of characteristics (fat, protein, total solids and no-fat solids contents). The results obtained from this study showed an average ranging from 34.06 to $38.60 \mathrm{~g} / \mathrm{l}, 30.01$ to $31.61 \mathrm{~g} / \mathrm{l}, 40.53$ to $42.52 \mathrm{~g} / \mathrm{l}, 116.03$ to $121.51 \mathrm{~g} / \mathrm{l}, 88.88$ to $90.85 \mathrm{~g} / \mathrm{l}, 9.87$ to $10 \%$ for FC, PC, LC, TS, SNF and Bx, respectively. On the other hand, an average ranging from 14.62 to $15.04 D^{\circ}, 6.68$ to 6.76, 1.0208 to 1.0494, 0.517 to 0.532 was showed for Ac, pH, Ds and FP, respectively. Furthermore, all milk samples tested for AT were, in most cases, normal at different concentrations of 79, 76, 74 and $68 \%$ while $T^{\circ}$ of all samples collected from bulk milk was under $06^{\circ} \mathrm{C}$. The present findings showed a good quality of the milk produced in this area in terms of chemical and physical criteria. Finally, the milk originated from Fkih Ben Saleh could be considered as an important riche and source of fabrication of dairy products with high quality.
\end{abstract}

Keywords: Milk, Physicochemical Quality, Fkih Ben Saleh Area, Beni Mellal-Khenifra Region

\section{INTRODUCTION}

Morocco has established successive strategies (multiple plans of development) in order to develop the dairy sector. In terms of consumption, the first plan aimed to increase milk consumption to 0.33 liters of milk per person per day [1]. The second one more ambitious; aimed to achieve the recommendations of the international organizations of food and health (FAO and WHO) which is of 90 liters equivalent per year and per inhabitant. Nowadays, with free trade agreements and open markets adopted by Moroccan government, local dairy products compete with imported products [2]. In this context, the local products quality is a determining factor to face and exceed this new challenge type. In 2013, dairy production in Morocco is close to 2.3 billion liters. A major part of this production is processed and packaged by dairy companies (around 70 to $80 \%$ ) before being served to consumers while the rest goes through the hawking circuit e.g. cafes and dairies "Mahlabat" [3].

In Morocco, the dairy sector contributes an average of 5\% to the volume of agricultural production and accounts for $10.7 \%$ of that of the agri-food industry. The Rabat-Salé-Kenitra region is the first dairy zone in the Kingdom, with a production of 522 million liters of milk, followed by the Beni Mellal-Khénifra, Casablanca-Settat and Marrakech-Safi regions, which provide 47\% of national milk production. The number of milk collection centers reached 2,800 in 2017 , with an overall collection capacity of 
more than 2.5 million liters of milk per day. Milk collected, which accounts for $64 \%$, on average, of milk production, is processed at 122 local industrial units [4].

The milk supply modes are diversified in Morocco. There are farms, cooperatives and collection centers. The farms are characterized by farms specialized in the production of milk. This specialization gives them a certain technicality in the sanitary and nutritional management of livestock, and therefore a control of the quality and quantity of milk produced. The second mode of supply studied, in this work, is represented by cooperatives. These are a much more complex mode of supply. This is well illustrated in the case of Beni-Mellal-Khénifra region which offers a good example of the organization of milk producers, and acts as an intermediary between small family farms and industry [5].

We previously reported on the general characteristics of raw cow milk in this region [20-21]. To more complete our knowledge on the full characteristics, we sought in this study to investigate other areas of this region. Thus, the main objective of the present study is to evaluate the Physical and Chemical Quality of cow raw milk in dairy herds located in the Fkih Ben Saleh area located in Beni mellal-Khenifra region.

\section{MATERIAL AND METHODS}

\subsection{Sampling zone}

This present work was performed in perimeter of the Fkih ben saleh area. This area is situated in Beni Mellal region, located in the north-centre of Morocco and has been chosen for their potential milk production in Tadla Plain. This part of Tadla Plain is well developed and the agriculture is generally based on irrigation methods and many farms and dairy unities have developed their activities inside them and there is a large milk production from cows and goats [6-7]. The climate is well-known to be semi-arid with a dry season from April to October and it is also characterized by a rainy season from November to March [8]. The annual cumulative rainfall varies from 149 to $397 \mathrm{~mm}$ between 2000 and 2013 while the seasonal variations of temperature are significant with a maximum in August of $46^{\circ} \mathrm{C}$, a minimum in January of $-6^{\circ} \mathrm{C}$ and an annual average of $20{ }^{\circ} \mathrm{C}$ [9].

\subsection{Sampling preparation}

A total of 240 samples of cow raw milk was collected into sterile bottles (about 1000ml) for physicochemical analysis from five farms randomly selected in these area and transported immediately in thermos-cool boxes (at $4^{\circ} \mathrm{C}$ ) to Biological Engineering Laboratory, Sultan Moulay Slimane University during a period extended from January to December of 2018.

\subsection{Physicochemical analysis}

After the collection of sample, the temperature parameter of the milk is firstly measured in place with a thermometer. Once raw milk samples arrived at laboratory in an insulated cooler containing ice cubes (thermos-cool boxes (at $\left.4^{\circ} \mathrm{C}\right)$ ). $\mathrm{The} \mathrm{pH}$ is directly measured using a pH-meter while titratable acidity is measured by titration with $1 \mathrm{~N} \mathrm{NaOH}$ in the presence of phenophthalein and acidity of milk was expressed in degrees Doronic $\left({ }^{\circ} \mathrm{D}\right)$ which is equivalent to a grade of $0.1 \mathrm{~g}$ of lactic acid/L of milk [10]; the milk density is determined using a thermo-lacto- densimeter. It is reduced to $20^{\circ} \mathrm{C}$ by the following formula: corrected density $=$ read density +0.2 (milk temperature $-20^{\circ} \mathrm{C}$ ). Concerning chemical criteria, the fat rate is firstly determined by the acid-butyrometric method of Gerber [11], which consists of an attack of milk with sulfuric acid and separation by centrifugation in the presence of isoamyl alcohol of the released fat [12-13] while the determination of the levels of proteins, fat, total solids, solids-non-fat is carried out using the milkoscan ${ }^{\mathrm{TM}}$ minor apparatus calibrated to official methods to determine the protein level (Kjeldal method), fat content (Gerber method) and total solids (desiccation method). The results are displayed directly on the screen or printed out; the results are expressed $\mathrm{g} / 100 \mathrm{~g}$. 
International Journal of Advances in Scientific Research and Engineering (ijasre), Vol 5 (6), June-2019

\section{RESULTS}

The important of the physicochemical results of raw cow's milk produced in Fkih ben saleh studied area of Beni Mellal region are presented in Table 1.

Table 1: Physicochemical analyzes average of raw milk obtained from Fkih ben saleh area.

\begin{tabular}{|c|c|c|c|c|c|c|c|c|c|c|c|c|c|c|c|}
\hline & $\begin{array}{c}\mathrm{FC} \\
(\mathrm{g} / \mathrm{kg})\end{array}$ & $\begin{array}{c}\mathrm{PC} \\
(\mathrm{g} / \mathrm{kg})\end{array}$ & $\begin{array}{c}\mathrm{LC} \\
(\mathrm{g} / \mathrm{kg})\end{array}$ & $\begin{array}{c}\mathrm{ST} \\
(\mathrm{g} / \mathrm{kg})\end{array}$ & $\begin{array}{c}\text { SNF } \\
(\mathrm{g} / \mathrm{kg})\end{array}$ & FP & $\begin{array}{l}\mathrm{Ac} \\
{ }^{\circ} \mathrm{D}\end{array}$ & Ds & $\begin{array}{r}\mathrm{Bx} \\
\%\end{array}$ & $\mathrm{pH}$ & $\begin{array}{l}\mathrm{T}^{\circ} \\
{ }^{\circ} \mathrm{C}\end{array}$ & $\begin{array}{c}\text { AT79\% } \\
(+)\end{array}$ & $\begin{array}{c}\text { AT76\% } \\
(+)\end{array}$ & $\begin{array}{c}\text { AT74\% } \\
(+)\end{array}$ & $\begin{array}{c}\text { AT68\% } \\
(+)\end{array}$ \\
\hline January & 36,19 & 31,27 & 41,83 & 119,85 & 90,5 & 0,521 & 14,78 & 1,0319 & 10 & 6,76 & 5,55 & $0,00 \%$ & $0,00 \%$ & $0,00 \%$ & $0,00 \%$ \\
\hline February & 36,27 & 30,9 & 42,01 & 119,76 & 90,12 & 0,523 & 14,72 & 1,0318 & 10 & 6,76 & 5,58 & $0,00 \%$ & $0,00 \%$ & $0,00 \%$ & $0,00 \%$ \\
\hline Mars & 35 & 30,01 & 41,33 & 117,84 & 88,88 & 0,517 & 14,8 & 1,0317 & 9,96 & 6,76 & 5,59 & $0,00 \%$ & $0,00 \%$ & $0,00 \%$ & $0,00 \%$ \\
\hline April & 34,67 & 30,08 & 41,07 & 118,15 & 90,14 & 0,524 & 14,62 & 1,0317 & 9,87 & 6,76 & 5,61 & $0,00 \%$ & $0,00 \%$ & $0,00 \%$ & $0,00 \%$ \\
\hline Mai & 34,72 & 30,73 & 42,67 & 118,37 & 90,85 & 0,532 & 14,85 & 1,0373 & 10 & 6,76 & 5,63 & $0,00 \%$ & $0,00 \%$ & $0,00 \%$ & $0,00 \%$ \\
\hline June & 34,69 & 30,32 & 42,44 & 117,7 & 89,79 & 0,525 & 14,88 & 1,0318 & 10 & 6,76 & 5,57 & $0,00 \%$ & $0,00 \%$ & $0,00 \%$ & $0,00 \%$ \\
\hline July & 34,06 & 30,36 & 42,2 & 116,03 & 89,46 & 0,522 & 14,92 & 1,0317 & 10 & 6,74 & 5,85 & $2,30 \%$ & $0,00 \%$ & $0,00 \%$ & $0,00 \%$ \\
\hline August & 34,96 & 30,67 & 42,52 & 117,7 & 90,14 & 0,526 & 14,85 & 1,0317 & 10 & 6,74 & 5,77 & $3,00 \%$ & $0,00 \%$ & $0,00 \%$ & $0,00 \%$ \\
\hline September & 35,43 & 30,93 & 42,17 & 118,33 & 90,25 & 0,532 & 14,88 & 1,0318 & 10 & 6,75 & 5,71 & $0,00 \%$ & $0,00 \%$ & $0,00 \%$ & $0,00 \%$ \\
\hline October & 36,48 & 31,31 & 40,98 & 119,78 & 90,35 & 0,522 & 15,04 & 1,0319 & 10 & 6,75 & 5,65 & $3 \%$ & $0,00 \%$ & $0,00 \%$ & $0,00 \%$ \\
\hline November & 38,58 & 31,61 & 40,53 & 120,88 & 89,96 & 0,518 & 14,88 & 1,0208 & 9,89 & 6,68 & 5,59 & $0,00 \%$ & $0,00 \%$ & $0,00 \%$ & $0,00 \%$ \\
\hline December & 38,6 & 30,87 & 40,83 & 121,51 & 90 & 0,526 & 14,97 & 1,0494 & 10 & 6,75 & 5,61 & $0,00 \%$ & $0,00 \%$ & $0,00 \%$ & $0,00 \%$ \\
\hline
\end{tabular}

According to results retained from this study; we observed, in all studied samples in this area, a variability average in the nutritional quality of raw milk from January to December month. Consequently, the milk FC average obtained was ranked from 34.06 in July month to $38.60 \mathrm{~g} / \mathrm{l}$ in December month. Moreover, the average values recorded of milk PC was ranged from 30.01 in Mars month to 31.61 in November month. Finally, an average ranging from 40.53 in November to $42.52 \mathrm{~g} / \mathrm{l}$ in August month, 116.03 in July to $121.51 \mathrm{~g} / \mathrm{l}$ in December month, 88.88 in Mars to $90.85 \mathrm{~g} / \mathrm{l}$ in Mai month, 9.87 in April to $10 \%$ in several months for LC, TS, SNF and Bx, respectively.

In relation to physical criteria, the result obtained of milk Dornic acidity collected from Fkih ben saleh area investigated was situated between 14.62 in April and $15.04 \mathrm{D}^{\circ}$ in October month. Moreover, the ionic acidity $(\mathrm{pH})$ is oscillated from 6.68 in November to 6.76 in several months. The measurement of milk Ds in this studied area ranged generally from 1.0208 in November to 1.0494 in December month while $\mathrm{T}^{\circ}$ of all samples collected from bulk milk was under $06^{\circ} \mathrm{C}$. Of note, $\mathrm{FP}$ was between 0.517 in Mars to 0.532 in Mai and September months. Finally, all milk samples tested for AT were, in almost cases, normal at different concentrations $79,76,74$ and $68 \%$.

\section{DISCUSSION}

The industrial quality of milk can be manifested by all the properties and physicochemical, biological and organoleptic characteristics required for ensure the production of high value dairy products commercial [14]. The findings found in this studied area revealed, in general, the presence of less variability values with regard to chemical and physical characteristics, depending in particular on the month and on the season. Thus, the average obtained was ranged from 34.06 to $38.60 \mathrm{~g} / \mathrm{l}, 30.01$ to $31.61 \mathrm{~g} / \mathrm{l}$, 
40.53 to $42.52 \mathrm{~g} / \mathrm{l}, 116.03$ to $121.51 \mathrm{~g} / \mathrm{l}, 88.88$ to $90.85 \mathrm{~g} / \mathrm{l}, 9.87$ to $10 \%$ for FC, PC, LC, TS, SNF and for Bx, respectively. Moreover, an average ranging from 14.62 to $15.04 \mathrm{D}^{\circ}, 6.68$ to $6.76,1.0208$ to $1.0494,0.517$ to 0.532 was showed for Ac, $\mathrm{pH}$, Ds and FP, respectively. Finally, all milk samples tested for AT were, in almost cases, normal at different concentrations of 79, 76, 74 and $68 \%$ while $\mathrm{T}^{\circ}$ of all samples collected from bulk milk was under $06{ }^{\circ} \mathrm{C}$.

According to authors, these results could be associated in particular to various major factors like the extensive utilization of concentrate type of feeding given to cows [15-16] an/or the farming practices used in this area [17-18].

The comparison of our findings in this study with those previously reported by Bassbassi et al.[19] from February to April in some cooperatives and farms in region of Fkih-ben-salh area, Kssiba area and Kalaa region especially for solids no-fat, protein and fat contents stay superior that what we found her particularly in farms case from Fkih-ben-salh: (fat: $41.05 \mathrm{~g} / \mathrm{kg}, \mathrm{protein}: 33.78 \mathrm{~g} / \mathrm{kg}$ and solids no-fat: $96.81 \mathrm{~g} / \mathrm{kg}$ ), Kssiba: (fat: $41.16 \mathrm{~g} / \mathrm{kg}$, protein: $33.02 \mathrm{~g} / \mathrm{kg}$ and solids no-fat: $96.67 \mathrm{~g} / \mathrm{kg}$ ) and from Kalaa: (fat: $38.28 \mathrm{~g} / \mathrm{kg}$, protein: $32.94 \mathrm{~g} / \mathrm{kg}$ and solids no-fat: $95.36 \mathrm{~g} / \mathrm{kg}$ ).

When the results obtained in this study is compared with those previously described by us in different areas situated in Beni mellal region including Fkih ben saleh area. In this previous study, we showed a variability average in the nutritional quality of raw milk between the different studied areas. In this regard, the milk FC average obtained was ranged from the high value of 37.6 obtained in the West-North to the low value of $33.4 \mathrm{~g} / 1$ recorded in the North-West areas of Beni mellal city. The other graded values: about 34.51 and $34.56 \mathrm{~g} / \mathrm{l}$ are also evidenced in West and North areas of Beni mellal city, respectively. Moreover, the average values recorded of milk PC was respectively about 29.8 (West-North area), 28.9 (North-West area), 27.8 (North area) and 30.6 g/l (North area) whereas the TS level was around 122.9, 115.9, 116.1 and $118.3 \mathrm{~g} / \mathrm{l}$, in the West-North, North-West, West and the North areas, respectively. Finally, an average of 86.0, 82.8, 82.1 and 85.6 g/l was also registered in these areas, respectively for SNF. Of note, the Bx average rate oscillated between 09 to $10 \%$ for all studied areas [20]. In general, these findings remain less than what we found in the present study in Fkih ben saleh area for almost of above described milk quality parameters such as FC, PC, TS and SNF. This notable difference showed a variability of nutritional milk quality between regions on the one hand and milk farms on the one other hand [20]. This variation could be also due to the geographical difference that leads to the variation of climatic conditions and the ways to feed livestock and is also related to breeding conditions adopted by the farms in each province [20].

When physical criteria is concerned, the result obtained of milk Dornic acidity collected from Fkih ben saleh area investigated in this study was situated between 14.62 in April and $15.04 \mathrm{D}^{\circ}$ in October month. Moreover, the ionic acidity $(\mathrm{pH})$ is oscillated from 6.68 in November to 6.76 in several months. The measurement of milk Ds in this studied area ranged generally from 1.0208 in November to 1.0494 in December month while $\mathrm{T}^{\circ}$ of all samples collected from bulk milk was under $06{ }^{\circ} \mathrm{C}$. Of note, FP was between 0.517 in Mars to 0.532 in Mai and September months. Finally, all milk samples tested for AT were, in almost cases, normal at different concentrations 79, 76, 74 and 68\%. These findings stay almost similar to those described by Hnini et al.[20] for the main fourth areas including Fkih ben saleh area especially for Ac (14.85, 15.25, 15.20 and $\left.15.65 \mathrm{D}^{\circ}\right)$, $\mathrm{pH}$ (is oscillated from 6.68 to 6.76). However, the measurement of milk density in Fkih ben saleh remains also similar to those previously advanced by Hnini et al.[20] in described areas including Fkih ben saleh, except in case of November and December months in our study which showed densities of 1.0208 and 1.0494, respectively. All milk samples tested for alcohol testing in this study was normal at different concentrations (AT79\%, AT76\%, AT74\% and AT68\%) were normal in contrast to Hnini et al.[20], which showed that all samples tested for AT were normal at $74 \%$ only.

The alcohol test is generally used as a rapid and simple indicator of milk freshness. According to this test, all milk samples tested were normal at different tested concentrations of alcohol. This test is also considered a practical means of determination the propensity of milk for heat coagulation. The other importance of this test that is allowed the detection of abnormal milk, such as colostrum, milk from animals in late lactation, milk from animals suffering from mastitis and milk in which mineral balance has been disturbed according to Hnini et al.[20]. However, the determination of the density and the freezing point as well as the brix 
of the raw milk was also evaluated in order to know if these milks have been previously exposed to the wetting by the farmers in order to increase the volume of raw milk sold for gain more money [21].

\section{CONCLUSION}

In general, this study showed a good quality for all parameters analysed of the milk produced at level of Fkih Ben Saleh area in terms of chemical and physical criteria. As a result, this milk originated from this area could be exploited as an important riche and source of fabrication of dairy products with high quality.

\section{REFERENCES}

[1] El Mekki, A.A. 2007. Chapitre 11-La filière lait et les produits laitiers au Maroc,” Annuels, pp. 291-311.

[2] Sraïri, M. Cholin Kuper, A. 2007. Conséquences de la libéralisation des marchés sur les opérateurs de la filière laitière au Maroc, Rev. Elev. Med. Vet. Pays Trop., 60: 177-187.

[3] Araba, A., Benjelloun, S., Hamama, A., Hamimaz, R., Zahar, M. 2001. Organisation de la filière laitière au Maroc, Options Mediterr. Ser. B, 32: 47-62.

[4] Situation et principales tendances de la filière laitière.https://www.libe.ma/Situation-et-principales-tendances-de-la-filierelaitiere_a103227.html (Consulted at 17.05.19)

[5] Le Gal, P.-Y., Oudin, E., Kuper, M., C.-H. Moulin, C.-H., Sraïri, M.T. 2007. Rôle des coopératives dans le fonctionnement du bassin de collecte laitier du Tadla, Maroc, Actes du troisième Atelier régional du Proj. Sirma, AFEID, p. 16.

[6] Ferdous, N,. Hnini, R., Chigr, F,. Najimi, M. 2017. Hygienic Quality of Raw Cow Milk Produced by Smallholder Dairy Farmers in Beni Mellel area in Morocco. World Journal of Research and Review (WJRR), 5: 09-16.

[7] Ferdous, N., Hnini, R., Merzouki, M., Bahi, L., Chigr, F., Najimi, M. 2017. Microbiological Characteristics of Raw Cow Milk in Beni Mellal Area (Morocco). International Journal of Science and Engineering Applications, Volume 6 Issue 10, ISSN2319-7560.

[8] Cherkaoui, F.Z., El Iamani, A., El Mansouri, L. 2004. Développement et pratique de la fertigation dans le périmètre irrigué du Tadla. IPI regional workshop on Potassium and Fertigation development in West Asia and North Africa; Rabat, Morocco.

[9] El Harti, A., Lhissou, R., Chokmani, K., Ouzemou, J., Hassouna, M., Bachaoui, E., El Ghmari, A. 2016. Spatiotemporal monitoring of soil salinization in irrigated Tadla Plain (Morocco) using satellite spectral indices. International Journal of Applied Earth Observation and Geoinformation, 50: 64-73.

[10] AFNOR (Association Française de Normalisation). 1980. Lait. Détermination de la matière sèche. NF VO4 207, In AFNOR (Ed.), Recueil de normes françaises. Laits et produits laitiers. Méthodes d'analyse. Paris : Normalisation française, P: 33-34.

[11] AFNOR (Association Française de Normalisation). 1993. Contrôle de la qualité des produits alimentaires- Lait et produits laitiers : analyses physicochimiques. Paris La Défense : AFNOR, 4e éd., P: 581.

[12] AFNOR (Association Française de Normalisation). 2001. Lait - Détermination de la teneur en matière grasse - Méthode gravimétrique (méthode de référence). NF EN ISO 1211, P: 21.

[13] N.M. 08.4.008 (Norme Marocaine NM 08.4.008) : Laits et produits dérivés, détermination de la teneur en matière grasse. Méthode acido-butyrométrique (Dite de Gerber). Ministère du Commerce et de l'Industrie, Service de Normalisation Industrielle Marocaine (SNIMA).

[14] Bérard, H.L., Rosell, J.M., Turgeon, J. 1936. L'influence de l'alimentation des vaches laitières sur la production de lait de bonne qualité industrielle. Le Lait, INRA Editions, 16 (160), pp.1068-1083. <hal-00895258>

[15] Houssin, B., Chenais, F., Forêt, A. 2003. Renc. Rech. Ruminants, 10: 219-222. 
[16] Houssini, B., Chenais, F., Hardy, A. 2004. Effect of the kind of nitrogen supplement of maize silage diet on the fat composition and the organoleptic and nutritionnal qualities of butters and camembert cheeses. Renc. Rech. Ruminants, 11.

[17] Afif, A., Faid, M., Najimi, M. 2007. Effects of breeding and hygienic practices on raw cow milk quality in Tadla area, Morocco. Livestock Research for Rural Development, 19 (12).

[18] Afif, A., Faid, M., Najimi, M. 2008. Qualité microbiologique du lait cru produit dans la région de Tadla au Maroc. Reviews in Biology and Biotechnology, 7: 2-7.

[19] Bassbasi, M., Hirri, A., Oussama, A. 2013. Caractérisation physico chimique du lait cru dans la région de Tadla-Kelaa au Maroc: Application de l'analyse exploratoire. International Journal of Innovation and Applied Studies, ISSN 2028-9324, 2: 512-517.

[20] Hnini, R., Ouhida, L., Chigr, M., Merzouki, M., Gammouh, A., Mohamed Najimi, M., Chigr, F. 2018. Evaluation of the Physical and Chemical Quality of Moroccan Cow Raw Milk in Dairy Herds Located in the Beni Mellal Region. World Journal of Research and Review (WJRR) 2455-3956, 7: 14-18.

[21] Hnini, R., Ihbour, S., Ouhida, L., Chigr, M., Merzouki, M., Bahi, L., Gammouh, A., Mohamed Najimi, M., Chigr, F. 2018. The physicochemical quality of raw milk sold at dairies of Beni Mellal city (Morocco). International Journal of Scientific \& Engineering Research 2229-5518, 9: 1511. 